\title{
Variability in ice motion and dynamic discharge from Devon Ice Cap, Nunavut, Canada
}

\author{
WESLEY VAN WYCHEN, ${ }^{1,2}$ JAMIE DAVIS, ${ }^{3}$ LUKE COPLAND, ${ }^{1}$ DAVID O. BURGESS, ${ }^{2}$ \\ LAURENCE GRAY, ${ }^{1}$ MARTIN SHARP, ${ }^{3}$ JULIAN A. DOWDESWELL, ${ }^{4}$ TOBY J. BENHAM ${ }^{4}$ \\ ${ }^{1}$ Department of Geography, University of Ottawa, Ottawa, Ontario, K1N 6N5, Canada \\ ${ }^{2}$ Natural Resources Canada, 601 Booth St., Ottawa, Ontario, K1A OE8, Canada \\ ${ }^{3}$ Department of Earth and Atmospheric Sciences, University of Alberta, Edmonton, Alberta, Canada \\ ${ }^{4}$ Scott Polar Research Institute, University of Cambridge, Cambridge CB2 1ER, UK \\ Correspondence: Wesley Van Wychen <wvanw046@uottawa.ca>
}

\begin{abstract}
Feature tracking of approximately annually separated Landsat-7 ETM+ imagery acquired from 1999 to 2010 and speckle tracking of 24-day separated RADARSAT-2 imagery acquired from 2009 to 2015 reveal that motion of the major tidewater glaciers of Devon Ice Cap is more variable than previously described. The flow of almost half (six of 14) of the outlet glaciers slowed over the observation period, while that of the terminus regions of three of 14 of the glaciers sped up in the most recent years of observation. The North Croker Bay Glacier of southern Devon Ice Cap showed the greatest variability in motion, oscillating between multi-year (three or more) periods of slower and faster flow and exhibited a pattern of velocity variability that is different from that of the rest of the ice cap's outlet glaciers. Comparisons between areas of dynamic variability and glacier bed topography indicate that velocity variability is largely restricted to regions where the glacier bed is grounded below sea level. Derived velocities are combined with measurements of ice thickness at the fronts of tidewater glacier to determine a mean annual $(2009 ; 2011-15)$ dynamic ice discharge of $0.41 \pm 0.11 \mathrm{Gt} \mathrm{a}^{-1}$ for Devon Ice Cap. The Belcher Glacier is becoming a larger source of mass loss via ice discharge.
\end{abstract}

KEYWORDS: Ice dynamics, Glacier discharge, Remote sensing

\section{INTRODUCTION}

The glaciers, icefields and ice caps of the Canadian High Arctic have become an increasingly important region of glacial mass loss in recent years as a result of higher summer air temperatures that have increased surface melt and run-off (Gardner and others, 2011, 2012; Sharp and others, 2011). Since climate projections, using moderate warming scenarios, indicate that increased mass losses from this region over the current century (due to enhanced meltwater production) are unlikely to be compensated for by increases in snowfall, regional ice-mass loss is likely to continue (Lenaerts and others, 2013). Although the amount of mass loss from Devon Ice Cap via dynamic discharge (ice flux to the ocean) has been determined previously at single snap-shots; for example, in the mid-1990s (e.g. Burgess and others, 2005; Shepherd and others, 2007), in 2009 (e.g. Van Wychen and others, 2012) and in 2012 (e.g. Van Wychen and others, 2014), the current mass loss via dynamic discharge, and its past variability, have not been well constrained. Here, we use a 15-year record of surface ice motion to quantify temporal variability in dynamics of the major tidewater terminating glaciers of Devon Ice Cap. This work complements that of Van Wychen and others (2016), who investigated variability in the flow of outlet glaciers draining the major ice masses of Axel Heiberg and Ellesmere Islands for the period 1999-2015, and identified three distinct modes of variability: surging, pulsing and consistent acceleration. Here, we use this same classification scheme to characterize the observed variability in glacier flow on Devon Ice Cap. When combined with the findings of Van Wychen and others (2016), the results presented here provide a comprehensive record of velocity variability and dynamic discharge from the ice masses of the Queen Elizabeth Islands (Devon, Ellesmere, Axel Heiberg Islands) from 1999 to 2015.

This paper builds upon the work of Van Wychen and others (2012), which investigated the change in surface velocities of Devon Ice Cap outlet glaciers between single snapshots in the mid-1990s and 2009. Although Van Wychen and others (2012) were able to identify regions of change between the two periods, the lack of surface ice-flow measurements during the intervening period precluded the characterization of the extent and magnitude of velocity variability during that time. Here, by utilizing a larger velocity dataset and bed profiles collected along the centerlines of tidewater glaciers, we provide a more complete assessment of the dynamics of Devon Ice Cap and of the nature and magnitude of spatial and temporal variations in the velocity of its major outlet glaciers. New velocity mapping from RADARSAT-2 imagery allows expansion and updating of the flow regime mapping originally completed by Burgess and others (2005) for Devon Ice Cap. Finally, we compute new estimates of annual dynamic discharge from the ice cap for the period 1999-2015. Here, we define dynamic discharge as mass passing through a fixed flux gate near the terminus of a marine terminating outlet glacier, but our estimates do not account for terminus advance or retreat.

\section{STUDY SITE}

Devon Ice Cap occupies the eastern portion of Devon Island (Fig. 1; inset) and had an area of $14400 \mathrm{~km}^{2}$ and a volume of $4400 \mathrm{~km}^{3}$ in 2000 (the last time full assessments of area and 


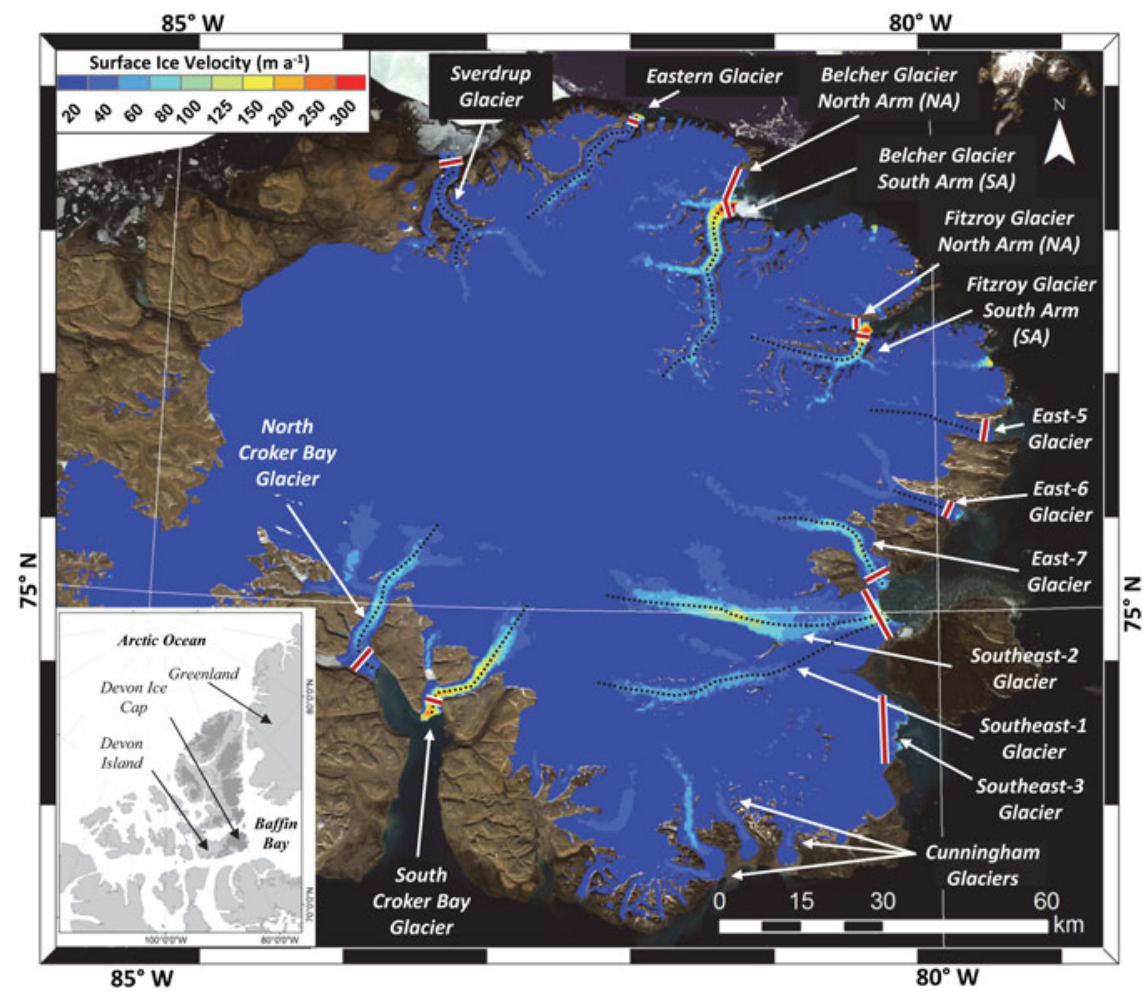

Fig. 1. Devon Ice Cap velocity structure derived from speckle tracking of RADARSAT-2 Wide Fine imagery acquired in winter 2015 overlain on a Landsat-7 image mosaic acquired 29 July and 2 August 2000. Red on white lines indicate locations of flux gates used to determine dynamic discharge estimates in Figure 2; black-dotted lines indicate locations of bed elevation and extracted velocity profiles shown in Figs 3, 4; Dark gray areas on inset map indicate glaciated terrain in the Canadian High Arctic.

volume were completed) (Burgess and Sharp, 2004; Dowdeswell and others, 2004). Mass-balance studies on Devon Ice Cap began in the 1960s (Koerner, 2005, Sharp and others, 2011), and indicate that very negative mass balances have become increasingly common since 2005 (Sharp and others, 2011). This has occurred in conjunction with an increase in summer air temperatures, particularly since the late 1980s (Gardner and Sharp, 2007).

Despite the long-term record of mass-balance observations, there have been fewer studies of the dynamics of Devon Ice Cap and little discussion of how regional dynamics have evolved over the past 15 years of warming summer climate or evaluation of the implications for the mass balance of the ice cap as a whole. Burgess and others (2005) provided the first regional assessment of surface velocities and an estimate of iceberg discharge $\left(0.52 \mathrm{Gt} \mathrm{a}^{-1}\right)$ from the ice cap using interferometric measurements based on ERS 1/2 data acquired in the mid-1990s and speckle tracking of RADARSAT-1 data acquired in 2000. Shepherd and others (2007) applied interferometry to the same ERS- $1 / 2$ datasets to derive ice motion and calculate ice discharge from the ice cap and combined this with modeled accumulation and surface run-off to determine the net mass balance of the ice cap and estimate its contribution to global sea level rise. Both studies found slow ice flow $\left(<10 \mathrm{~m} \mathrm{a}^{-1}\right)$ in the ice-cap interior (indicative of ice frozen to its bed) and faster ice flow within its outlet glaciers. Burgess and others (2005) classified the flow of Devon Ice Cap into four distinct regimes, based on the relationship between the ratio of surface velocity to ice thickness and the driving stress. This classification was used to identify regions where basal sliding was inferred to be an increasingly important component of overall ice motion. Wyatt and Sharp (2015) used
Landsat-7 ETM+ imagery to map the supraglacial drainage network on the ice cap and determined surface velocities of its major outlet glaciers. They found that interannual velocity variability was greatest near meltwater sink points (e.g. moulins) located in regions characterized by flow regimes that Burgess and others (2005) had suggested were associated with flow by basal sliding. They took this to be indicative of local hydrological forcing of basal sliding.

Van Wychen and others (2012) used speckle tracking of RADARSAT-2 fine beam imagery acquired in winter 2009 to determine the surface velocity structure of the entire ice cap. The velocity patterns were broadly similar in both imaging periods (i.e. mid-1990s and 2009). However, differencing of the velocity maps produced by the two studies revealed some areas of dynamic change. The most extensive difference was in the lowermost $10 \mathrm{~km}$ of East-5 Glacier, which was flowing $100 \mathrm{~m} \mathrm{a}^{-1}(1000 \%)$ faster in 2009 than in the mid-1990s. The surface velocities of the lower $20 \mathrm{~km}$ of the Southeast-2 Glacier had also increased by $\sim 50 \mathrm{~m} \mathrm{a}^{-1}$ (500-750\%). This was interpreted to be the result of downglacier propagation of a surge front previously described by Burgess and Sharp (2008). Despite these areas of dynamic difference, the computed mass loss via discharge computed by the two studies was identical (within error margins). This was because the measured surface velocities of the glaciers that are the largest sources of mass loss by dynamic discharge (Belcher, Fitzroy, Eastern, North Croker Bay and South Croker Bay Glaciers) had changed little between the two time periods.

\section{METHODS}

This study determines the velocity history of the major outlet glaciers of Devon Ice Cap using feature tracking of pairs of 
Landsat-7 ETM+ scenes with $~ 1$ year separation acquired in summer (May/September) from 1999 to 2010 (Table 1) and speckle tracking of 24-day separation pairs of winter/spring (January/April) RADARSAT-2 scenes acquired from 2009 to 2015 (Table 2). Speckle tracking of the RADARSAT-2 scenes allows ice motion to be determined over the entire ice cap, but only provides a 'winter' snapshot of velocities, as the method only works well when there is little change in the glacier surface properties between image acquisitions (e. g. minimal melt). Feature tracking of optical imagery provides a better record of 'annual' ice displacements as summer images are typically used. Thus, these estimates take account of any enhanced flow in summer associated with the input of supraglacial meltwater to the glacier bed. However, feature tracking is restricted to regions where there are distinctive surface features (e.g. crevasses) to track. This restricts the use of the method to the faster flowing regions of outlet glaciers.

\subsection{Feature tracking of Landsat-7 ETM+ imagery}

An automated, variable block-size correlation algorithm (developed within MATLAB ${ }^{\mathrm{TM}}$ ) was implemented in the frequency domain to derive glacier surface displacements from the panchromatic $(15 \mathrm{~m})$ band of Landsat-7 ETM+ imagery. This method is similar to that of Haug and others (2010) in that it applies a cross-correlation algorithm to match co-registered intensity gradient images accurately.
However, after matching has been completed using the initial correlation block window size $(64 \times 64$ pixels; 960 $\mathrm{m} \times 960 \mathrm{~m}$ ), which has been identified as a suitable window size for outlet glaciers on Devon Ice Cap (Wyatt and others, 2015)), and motion vectors have been determined, a nearest-neighbor filter is applied to the velocity field to identify mismatches automatically. This nearestneighbour filter identifies and removes displacements that differ greatly in either their orientation or magnitude compared with the average of the nearest eight neighbours (Sharp and others, 2014; Van Wychen and others, 2016). For each identified mismatch, the algorithm increases the block size automatically and the cross-correlation algorithm is re-run (the amount that the block size increases is predefined by the user and is based on the expected spatial gradient in surface velocities of the glacier being investigated). This process continues until the algorithm either no longer identifies mismatches or a maximum, user-defined block window size is reached. The maximum, user-defined block window size is based on the highest likely surface velocity of the glacier being investigated. This approach is computationally efficient for determining motion on glaciers with large spatial gradients in surface motion (e.g. glaciers with flow speeds ranging from tens to hundreds of $\mathrm{m} \mathrm{a}^{-1}$ ) and/or for glaciers that exhibit large temporal variations in motion (e.g. surge-type glaciers) (Sharp and others, 2014; Van Wychen and others, 2016).

Table 1. Summary of Landsat-7 ETM+ image pairs used to derive velocity maps via the feature tracking method

\begin{tabular}{|c|c|c|c|c|c|c|}
\hline Image date $1(\mathrm{dd} / \mathrm{mm} / \mathrm{yy})$ & Path & Row & Image date 2 (dd/mm/yy) & Path & Row & Glaciers \\
\hline $13 / 07 / 99$ & 38 & 6 & $24 / 07 / 00$ & 37 & 6 & $\mathrm{BL}, \mathrm{SV}, \mathrm{ES}, \mathrm{FZ}$ \\
\hline 06/07/99 & 37 & 7 & $24 / 07 / 00$ & 37 & 7 & $\mathrm{NC}, \mathrm{SC}$ \\
\hline 05/10/99 & 34 & 7 & 03/09/00 & 36 & 7 & SE1, SE2 \\
\hline $25 / 08 / 00$ & 37 & 6 & 28/08/01 & 37 & 6 & $\mathrm{BL}, \mathrm{SV}, \mathrm{ES}, \mathrm{FZ}$ \\
\hline $24 / 07 / 00$ & 37 & 7 & 20/07/01 & 37 & 6 & $\mathrm{NC}, \mathrm{SC}$ \\
\hline 03/09/00 & 36 & 7 & $21 / 08 / 01$ & 36 & 6 & SE1, SE2 \\
\hline 28/08/01 & 37 & 7 & $31 / 08 / 02$ & 37 & 7 & $\mathrm{NC}, \mathrm{SC}$ \\
\hline 21/08/01 & 36 & 7 & 09/09/02 & 36 & 7 & SE1, SE2 \\
\hline 07/09/02 & 38 & 6 & $25 / 08 / 03$ & 38 & 6 & $\mathrm{BL}, \mathrm{SV}, \mathrm{ES}, \mathrm{FZ}$ \\
\hline $31 / 08 / 02$ & 37 & 7 & 19/09/03 & 37 & 7 & $\mathrm{NC}, \mathrm{SC}$ \\
\hline 09/09/02 & 36 & 7 & 20/08/03 & 35 & 7 & SE1, SE2 \\
\hline $25 / 08 / 03$ & 38 & 6 & $12 / 09 / 04$ & 38 & 6 & $\mathrm{BL}, \mathrm{SV}, \mathrm{ES}, \mathrm{FZ}$ \\
\hline $25 / 08 / 03$ & 38 & 7 & $10 / 07 / 04$ & 38 & 7 & NC, SC \\
\hline $12 / 09 / 04$ & 38 & 6 & 14/08/05 & 38 & 6 & $\mathrm{BL}, \mathrm{SV}, \mathrm{ES}, \mathrm{FZ}$ \\
\hline 01/06/04 & 37 & 7 & 06/06/05 & 35 & 7 & $\mathrm{NC}, \mathrm{SC}$ \\
\hline $31 / 08 / 04$ & 34 & 7 & 09/08/05 & 35 & 7 & SE1, SE2 \\
\hline $14 / 08 / 05$ & 38 & 6 & $26 / 08 / 06$ & 37 & 6 & $\mathrm{BL}, \mathrm{SV}, \mathrm{ES}, \mathrm{FZ}$ \\
\hline $31 / 07 / 05$ & 36 & 7 & 09/07/06 & 37 & 7 & $\mathrm{NC}, \mathrm{SC}$ \\
\hline 09/08/05 & 35 & 7 & 06/09/06 & 35 & 7 & SE1, SE2 \\
\hline $26 / 08 / 06$ & 37 & 6 & $29 / 08 / 07$ & 37 & 6 & $\mathrm{BL}, \mathrm{SV}, \mathrm{ES}, \mathrm{FZ}$ \\
\hline 09/07/06 & 37 & 7 & 05/07/07 & 36 & 7 & NC, SC \\
\hline 06/09/06 & 34 & 7 & $31 / 08 / 07$ & 35 & 7 & SE1, SE2 \\
\hline 29/08/07 & 37 & 6 & $31 / 08 / 08$ & 37 & 6 & $\mathrm{BL}, \mathrm{SV}, \mathrm{ES}, \mathrm{FZ}$ \\
\hline $14 / 09 / 07$ & 37 & 7 & 24/08/08 & 36 & 7 & NC, SC \\
\hline $31 / 08 / 07$ & 35 & 7 & 26/08/08 & 34 & 7 & SE1, SE2 \\
\hline $31 / 08 / 08$ & 37 & 6 & 25/08/09 & 38 & 6 & $\mathrm{BL}, \mathrm{SV}, \mathrm{ES}, \mathrm{FZ}$ \\
\hline $24 / 08 / 08$ & 36 & 7 & 02/08/09 & 37 & 7 & NC, SC \\
\hline 26/08/08 & 34 & 7 & $27 / 08 / 09$ & 36 & 7 & SE1, SE2 \\
\hline $25 / 08 / 09$ & 38 & 6 & 06/09/10 & 37 & 6 & $\mathrm{BL}, \mathrm{SV}, \mathrm{ES}, \mathrm{FZ}$ \\
\hline
\end{tabular}

BL, Belcher Glacier; SV, Sverdrup Glacier; ES, Eastern Glacier; FZ, Fitzroy Glacier; NC, North Croker Bay Glacier; SC, South Croker Bay Glacier; SE1, Southeast-1 Glacier; SE2, Southeast-2 Glacier; Glacier locations are denoted on Figure 1. 
Table 2. Summary of RADARSAT-2 image pairs used to derive velocity maps of Devon Ice Cap via the speckle tracking method

RADARSAT-2 Speckle Tracking Imagery

\begin{tabular}{|c|c|c|c|c|}
\hline Image date $1(\mathrm{dd} / \mathrm{mm} / \mathrm{yy})$ & Image date $2(\mathrm{dd} / \mathrm{mm} / \mathrm{yy})$ & Beam mode and resolution & Segments & Glaciers \\
\hline 01/03/09 & $25 / 03 / 09$ & Fine $(9 \mathrm{~m})$ & 3 & $\mathrm{SV}, \mathrm{NC}, \mathrm{SC}$ \\
\hline 02/03/09 & $26 / 03 / 09$ & Fine $(9 \mathrm{~m})$ & 3 & $\mathrm{BL}$ \\
\hline 05/03/09 & 29/03/09 & Fine $(9 \mathrm{~m})$ & 3 & FZ, E5, E6, E7, SE1, SE2, SE3 \\
\hline $07 / 02 / 10$ & $03 / 03 / 10$ & Ultrafine (3 m) & 1 & $\mathrm{BL}$ \\
\hline $17 / 02 / 10$ & $13 / 03 / 10$ & Ultrafine (3 m) & 1 & SE1, SE2, E7 \\
\hline $20 / 02 / 10$ & $16 / 03 / 10$ & Ultrafine (3 m) & 1 & SV \\
\hline $21 / 02 / 10$ & $17 / 03 / 10$ & Ultrafine $(3 \mathrm{~m})$ & 1 & $\mathrm{NC}, \mathrm{SC}$ \\
\hline $16 / 02 / 11$ & $12 / 03 / 11$ & Fine $(9 \mathrm{~m})$ & 2 & FZ, E5, E6, E7, SE1, SE2 \\
\hline $11 / 03 / 11$ & 04/04/01 & Fine $(9 \mathrm{~m})$ & 3 & $\mathrm{BL}, \mathrm{ES}$ \\
\hline 03/04/01 & $27 / 04 / 11$ & Fine $(9 \mathrm{~m})$ & 3 & $\mathrm{NC}, \mathrm{SC}, \mathrm{SV}$ \\
\hline $07 / 02 / 12$ & $02 / 03 / 12$ & Wide Ultrafine $(3 \mathrm{~m})$ & 1 & SV \\
\hline 09/04/12 & 03/05/12 & Wide Fine $(9 \mathrm{~m})$ & 1 & BL, NC, SC, SE1, SE2, SE3, E5, E6, E7, FZ \\
\hline $31 / 12 / 12$ & $24 / 01 / 13$ & Wide Fine $(9 \mathrm{~m})$ & 1 & SV \\
\hline 05/01/13 & $29 / 01 / 13$ & Wide Fine $(9 \mathrm{~m})$ & 1 & BL, NC, SC, SE1, SE2, SE3, E5, E6, E7, FZ \\
\hline $02 / 12 / 14$ & $26 / 12 / 14$ & Wide Fine $(9 \mathrm{~m})$ & 1 & SV \\
\hline $07 / 12 / 14$ & $31 / 12 / 14$ & Wide Fine $(9 \mathrm{~m})$ & 1 & BL, NC, SC, SE1, SE2, SE3, E5, E6, E7, FZ \\
\hline $26 / 12 / 15$ & $01 / 01 / 15$ & Wide Fine $(9 \mathrm{~m})$ & 1 & SV \\
\hline $07 / 02 / 15$ & $03 / 03 / 15$ & Wide Fine $(9 \mathrm{~m})$ & 1 & $\mathrm{BL}, \mathrm{NC}, \mathrm{SC}, \mathrm{SE} 1, \mathrm{SE} 2, \mathrm{SE} 3, \mathrm{E} 5, \mathrm{E} 6, \mathrm{E} 7, \mathrm{FZ}$ \\
\hline
\end{tabular}

BL, Belcher Glacier; SV, Sverdrup Glacier; ES, Eastern Glacier; FZ, Fitzroy Glacier; NC, North Croker Bay Glacier; SC, South Croker Bay Glacier; SE1, Southeast-1 Glacier; SE2, Southeast-2 Glacier; SE3, Southeast-3 Glacier; E5, East-5 Glacier; E6, East-6 Glacier; E7, East-7 Glacier; Glacier locations are denoted on Figure 1.

\subsection{Speckle tracking of RADARSAT-2 imagery}

We apply a custom-written MATLAB ${ }^{\mathrm{TM}}$ speckle tracking script to RADARSAT-2 imagery to determine the velocity structure of Devon Ice Cap, as has been applied in previous studies of glacier motion in the Canadian Arctic (Short and Gray, 2004, 2005; Van Wychen and others, 2012, 2014, 2015, 2016) and Svalbard (Schellenberger and others, 2016). Here, we use RADARSAT-2 single-look complex (SLC) Fine and Wide Fine, and Ultrafine and Wide Ultrafine, beam mode datasets all of which perform well for determining ice motion at the scale of Devon Ice Cap (Van Wychen and others, 2012, 2014, 2016). Fine and Wide Fine SLC products have a resolution of $4.7 \mathrm{~m} \times 5.1 \mathrm{~m}$ in slant-range and azimuth, respectively, while Ultrafine and Wide Ultrafine SLC products have a resolution of $1.3 \mathrm{~m} \times 2.1 \mathrm{~m}$ in slantrange and azimuth, respectively. For the method to perform well, the surface ice structure must remain relatively undisturbed between image acquisitions (e.g. little snowfall, rainfall or melt, or rotation of crevasses) we therefore acquired imagery in the winter to early spring (December to late-April), when many of these changes are minimal. Our method of deriving displacements uses a normalized cross-correlation algorithm to determine the relative motion between two accurately coregistered pairs of RADARSAT-2 images (co-registration is completed automatically using a cross-correlation technique). Displacements are determined in both the azimuth and range directions of the image, using chip sizes of 101 pixels in both range and azimuth (corresponding to image chips of $510 \mathrm{~m} \times 470 \mathrm{~m}$ for Fine and Wide Fine data and $210 \mathrm{~m} \times 130 \mathrm{~m}$ for Ultrafine and Wide Ultrafine data, respectively). The 1: 250000 Canadian Digital Elevation Dataset (CDED) with $100 \mathrm{~m}$ grid spacing is used to remove the topographic component of the slant-range displacement and allow the conversion from the slant-range to ground-range displacement. The CDED was created from stereo pairs of airborne photographs acquired in the late 1950s and early 1960s for the Canadian High Arctic, and provides the best currently available comprehensive elevation dataset for the Canadian Arctic. We assume that ice motion is parallel to the surface slope. Displacements are calibrated using areas of known (zero) velocity (e.g. bedrock outcrops) and final velocities are standardized to annual values.

\subsection{Removal of erroneous displacements and production of velocity rasters}

Although the feature tracking and speckle tracking methods provide good results over most areas of interest, mismatches still occur. Mismatches arise when the cross-correlation algorithms find a stronger correlation with an incorrect image chip than with the true image chip. As a consequence, velocity results were imported into ESRI ArcGIS 10.1 for manual verification and filtering. To identify erroneous points, the following criteria were used (following Van Wychen and others, 2012, 2014): (1) Due to lateral friction, motion should be faster along the glacier centerline than at the margins; (2) flow vectors should be oriented parallel to surface flow features (e.g. lateral moraines and flow stripes) and topography (e.g. valley walls); and (3) motion should be consistent in both magnitude and orientation over short distances. Any displacements that did not conform to these criteria were removed from the dataset and all velocity points were inspected manually. An inverse distance weighting interpolation method (which provides a conservative approach to interpolation as the interpolated values cannot exceed those determined by the cross-correlation technique) was used to produce a continuous raster surface from the filtered displacements. Feature tracking displacements were posted to a $50 \mathrm{~m}$ grid spacing, while speckle-tracking displacements were posted to a $100 \mathrm{~m}$ grid spacing.

\subsection{Ice displacement error analysis}

For feature tracking, the overall error arises from both the systematic error (associated with co-registration) and the 
random error (which arises due to the way in with the crosscorrelation algorithm selects the sub-pixel location of the maximum correlation peak). The systematic error was $<1$ pixel (a maximum of $15 \mathrm{~m}$ for Landsat-7 ETM+ panchromatic imagery), following the co-registration method of Wyatt and Sharp (2015) that was also used in this study. A conservative estimate for the random error is \pm 0.5 pixels, which equates to $7.5 \mathrm{~m}$ for Landsat-7 ETM+ panchromatic imagery. Together, these errors combine to provide an overall velocity error of $\pm 22.5 \mathrm{~m} \mathrm{a}^{-1}$. This level of error is consistent with the uncertainty bounds for feature tracking of Landsat-7 ETM+ imagery reported by other studies (e.g. Haug and others, 2010; Waechter and others, 2015, Wyatt and Sharp, 2015, Van Wychen and others, 2016).

To assess the error associated with our speckle tracking datasets, we masked out the glaciated area and extracted velocities from adjacent non-glaciated terrain (e.g. bedrock outcrops). Additionally, to assess error in the higher elevation regions of the ice cap, we also extracted velocities along ice divides (obtained from the Randolph Glacier Inventory (Pfeffer and others, 2014)). We then computed the root sum of squares from both the bedrock error and ice divide error in all years. This provides an uncertainty of $\pm 6.0 \mathrm{~m} \mathrm{a}^{-1}$ for the speckle tracking dataset, which is similar to the error quoted by previous studies using the same methodology (e.g. Short and Gray, 2004, 2005; Van Wychen and others, 2012, 2014, 2016; Waechter and others, 2015).

\subsection{Glacier bed profile}

Bed elevation profiles for Fitzroy, East-5, East-6, East-7, Sverdrup and Eastern glaciers (locations provided in Fig. 1) were obtained from airborne ice-penetrating RADAR (100 $\mathrm{MHz}$ ) measurements collected over Devon Ice Cap in 2000 (Dowdeswell and others, 2004). These elevation profiles were collected approximately along the centerlines of the major outlet glaciers of the ice cap and have an error of $\pm 10 \mathrm{~m}$ (details on error analysis and data processing are available in Dowdeswell and others, 2004). For Belcher, North Croker Bay, South Croker Bay, Southeast-1 and Southeast-2 Glaciers, we used the updated 2012 Operation IceBridge dataset to derive the glacier bed elevation profiles, which also have an uncertainty of $\pm 10 \mathrm{~m}$ (Gogineni, 2012).

\subsection{Flow regime mapping}

Burgess and others (2005) used the relationship between the driving stress $\left(\tau_{\mathrm{d}}\right)$ and the ratio of the surface velocity to the ice thickness $(v / h)$ to classify the motion of Devon Ice Cap into four distinct 'flow regimes'. When ice flow occurs due to ice deformation alone, $(v / h)$ represents the mean shear strain rate through the ice column, but when basal motion contributes to ice flow the ratio of $\left(\tau_{\mathrm{d}}\right)$ to $(\mathrm{v} / \mathrm{h})$ provides a measure of the effective viscosity of the glacier system (with units of Pascal seconds) (Burgess and others, 2005). These flow regimes provide useful insight into the causes of the velocity structure of the ice cap, by identifying the regions in which flow is most influenced by basal sliding or internal deformation, and therefore which areas which may be most sensitive to external forcing. A full review of the classification and interpretation of these flow regimes is available in Burgess and others (2005), but briefly:
- Flow regime 1 (FR1: $v / h<0.075 \mathrm{a}^{-1}$, high positive correlation with $\tau_{\mathrm{d}}$ ) represents areas where ice is frozen to its bed and motion is solely by internal deformation;

- Flow regime 2 (FR2: $v / h>0.075 \mathrm{a}^{-1}$ and $<0.28 \mathrm{a}^{-1}$ ) represents regions where the basal ice temperature is at or approaching the pressure-melting point and basal motion (or enhanced deformation of basal ice) begins to contribute to overall motion;

- Flow regime 3 (FR3: $v / h>0.28 \mathrm{a}^{-1}, \tau_{\mathrm{d}}>0.075 \mathrm{MPa}$ ) is characterized by a further reduction in the viscosity of the ice and a greater contribution of basal motion to overall surface velocity;

- Flow regime 4 (FR4; $v / h>0.28 \mathrm{a}^{-1}, \tau_{\mathrm{d}}<0.075 \mathrm{MPa}$ ) represents areas of low basal friction, which indicate high basal motion and may suggest that deformation of subglacial sediments is playing a role in overall ice motion.

Here we update and expand the flow regime mapping for Devon Ice Cap, with $\tau_{\mathrm{d}}$ derived from:

$$
\tau_{\mathrm{d}}=\rho_{\mathrm{i}} g h \sin \alpha
$$

where $\rho_{\mathrm{i}}$ is the density of ice $\left(910 \mathrm{~kg} \mathrm{~m}^{-3}\right), g$ is the acceleration due to gravity $\left(9.81 \mathrm{~m} \mathrm{~s}^{-2}\right)$ and $\alpha$ is the surface slope. The influence of local variations in ice surface topography was removed by averaging the surface slope over distances of ten times the ice thickness. We mapped flow regimes for all years with velocity data that cover the entire surface of Devon Ice Cap (2009, 2011-15). A final flow regime map (Fig. 4) was produced by mosaicking all individual rasters together and selecting the majority class (mode) value for all overlapping points. A low-pass $(3 \times 3$ pixel $)$ filter was used to smooth the data and eliminate small features, which are likely related to artifacts in the input datasets.

\subsection{Calculation of dynamic discharge}

To calculate the dynamic discharge from the ice cap, we combined our surface ice velocities (derived both from feature tracking of Landsat-7 ETM+ imagery and speckle tracking of RADARSAT-2 data) with measured and interpolated ice thicknesses to determine the mass passing through defined flux gates at the fronts of the tidewater-terminating glaciers of Devon Ice Cap. These flux gates are located within $1-5 \mathrm{~km}$ of the calving front and are fixed in time and space (locations of flux gates are denoted on Fig. 1). These estimates of dynamic discharge do not account for mass changes due to terminus advance or retreat.

For 10 of the 11 major outlet glaciers of Devon Ice Cap, ice thickness measurements were acquired perpendicular to ice flow as part of NASA's Operation IceBridge airborne spring 2012 campaign. These measurements were collected using the Multichannel Coherent RADAR Depth Sounder (MCoRDS). Here we use the MCoRDS post-processed L2 dataset, which includes measurements of time, latitude, longitude, elevation, glacier surface elevation, glacier bed elevation and ice thickness (Gogineni, 2012). The ice thickness measurements have an uncertainty of $\pm 10 \mathrm{~m}$ (Gogineni, 2012) and are used to create flux gates where the entire cross-sectional morphology of the glacier is known.

To create a flux gate for East-5 Glacier (the only glacier lacking flow-perpendicular ice thickness measurements from the IceBridge campaign), we extracted ice thicknesses every $20 \mathrm{~m}$ across a profile located $1 \mathrm{~km}$ from the calving 
front that was derived from an interpolated raster of ice thicknesses measured on Devon Ice Cap in 2000 (Dowdeswell and others, 2004). Uncertainty in this dataset is $\pm 10 \mathrm{~m}$, although the 9-15-year gap between the acquisition of this dataset and the imagery used in this study means that those measurements possibly overestimate the current ice thickness of the East-5 Glacier (ICESat altimetry measurements indicate the maximum surface thinning of $\sim 2.5 \mathrm{ma}^{-1}$ between 2004 and 2009 (Gardner and others, 2011)). As a consequence, we apply this thinning rate to the centerline ice thickness measurement in order to account for the resulting ice loss.

To obtain the maximum and minimum estimates of the mass passing through each segment of a flux gate, we use the following equations:

$$
\begin{gathered}
Q_{\min }=\left(0.8 \times\left(V-V_{\text {error }}\right)\right) \times\left(H-H_{\text {error }}\right) \times(W), \\
Q_{\max }=\left(V+V_{\text {error }}\right) \times\left(H+H_{\text {error }}\right) \times(W),
\end{gathered}
$$

where for each segment width $(W, 20 \mathrm{~m}), V$ is the velocity extracted from the surface ice motion datasets, $V_{\text {error }}$ is the error associated with the velocity mapping, $H$ is ice thickness, and $H_{\text {error }}$ is the ice thickness error $( \pm 10 \mathrm{~m})$. For $Q_{\min }$ we use $80 \%$ of the surface velocity to characterize the depth-averaged velocity (Paterson, 1994), while for $Q_{\max }$ we assume that all motion occurs due to basal sliding and that the depth-averaged velocity is equivalent to the surface motion. To derive the minimum and maximum estimates of the ice flux from each glacier, $Q_{\min }$ and $Q_{\max }$ are summed (separately) across the entire width of the flux gate. The dynamic discharges reported here are the averages of the estimates of the total $Q_{\min }$ and $Q_{\max }$ the values of $Q_{\min }$ and $Q_{\max }$ then provide the lower and upper uncertainty bounds.

\section{RESULTS}

\subsection{Ice dynamics}

Glacier velocities on Devon Ice Cap are typically low (Fig. 1), with the interior regions of the ice cap moving at $<20 \mathrm{~m} \mathrm{a}^{-1}$, suggestive of ice frozen to its bed. Surface velocities $>20 \mathrm{~m}$ $\mathrm{a}^{-1}$ occur on outlet glaciers, with the highest velocities on tidewater glaciers. The ice motion described here conforms to previous measurements derived for the ice cap (e.g. Burgess and others, 2005; Shepherd and others, 2007; Van Wychen and others, 2012, 2014), with topography providing the dominant control on overall ice dynamics. Higher flow rates occur mainly in the eastern sector of the ice cap, where accumulation rates are higher (Koerner, 1979; Mair and others, 2005) and flux is dominated by flow through confined bedrock valleys. Slower interior flow (by ice deformation) dominates over the flat, plateau-like topography of the western sector, as previously described by Dowdeswell and others (2004). The highest ice velocities observed $\left(\sim 300 \mathrm{~m} \mathrm{a}^{-1}\right)$ occur at the termini of Belcher and Fitzroy glaciers, while velocities of $60-150 \mathrm{~m} \mathrm{a}^{-1}$ are typically found at the fronts of all other tidewater outlet glaciers.

\subsection{Areas of dynamic change}

In assessing temporal variations in ice motion, it is important to distinguish between variations due to differences in measurement period and variations due to changes in ice dynamics. In particular, it is likely that our velocities derived from feature tracking of annually separated optical images include some enhanced motion in the summer (Cress and Wyness, 1961; Danielson and Sharp, 2013; Wyatt and Sharp, 2015), which does not contribute to velocities derived from speckle tracking of winter RADARSAT-2 imagery. To quantify this effect, we compare 495363 points located on six major outlet glaciers (Belcher, Sverdrup, North Croker Bay, South Croker Bay, Southeast-1 and Southeast-2; Fig. 1) for which surface displacements were derived using both methods. We find that velocities derived from speckletracking were, on average, $11 \%$ lower than those derived using feature tracking. This difference seems to increase in a down-glacier direction, with the average difference in velocity between the Landsat-7 and RADARSAT-2 data across the flux gate locations on the six largest tidewater-terminating glaciers (Belcher, North Croker Bay, South Croker Bay, Sverdrup, Fitzroy, Eastern) ranging from 9\% less for Belcher Glacier to $27 \%$ less for North Croker Bay Glacier for velocities derived from the speckle tracking method (Fig. 2). The combined mean difference at the lowermost fluxgates for these six glaciers was $19 \%$. This bias arises from the fact that velocities derived from RADARSAT-2 imagery do not include enhanced summer motion associated with events such as summer melt and/or changes in sea-ice conditions at glacier termini.

It is likely that Landsat-7 ETM+ derived velocities should be relatively uniform across a flux gate, representing periods of plug flow when basal and lateral stresses are reduced due to the input of meltwater into the subglacial drainage network. However, this phenomenon is not always evident in the results presented in Figure 2 (e.g., 2008/09 Landsat-7 velocities for South Croker Bay and Belcher Glaciers). This likely results from our velocity interpolation method, which includes non-moving bedrock outcrops in ice-marginal locations and therefore results in lower velocities than might be expected in these regions. The velocity results in these ice marginal regions should therefore be treated with caution, although they do not make a significant difference to the overall dynamic discharge calculations.

In order to integrate the two datasets to produce a time series of glacier velocity change for the entire period of study, we only consider velocity changes between years to be significant if they are greater than the combined 11-19\% seasonal variability and error associated with each method. When assessing the significance of velocity changes detected by comparison of velocity fields derived using the same method, only the error associated with that method needs to be taken into account. As such, the resulting estimates of annual mass loss via dynamic discharge should be considered conservative because they do not take into account the effects of changes in glacier terminus position. Note that glacier termini were generally stable during the study period (e.g. Sverdrup, Eastern: 200-400 m retreat between 2000 and 2016), or retreating (e.g. Belcher, Fitzroy, Southeast-1, Southeast-2, Southeast-3, South Croker Bay, North Croker Bay: 800-2200 m retreat between 2000 and 2016). We do note the advance of East- 5 glacier ( $400 \mathrm{~m}$ since between 2000 and 2015), however based on the steady advance over this period we do not attribute it to surging.

Data on vertical motion at the termini of outlet glaciers on Devon Ice Cap are limited to dual-frequency GPS measurements along the centerline of Belcher Glacier (Danielson and Sharp, 2013). The maximum vertical motion on 


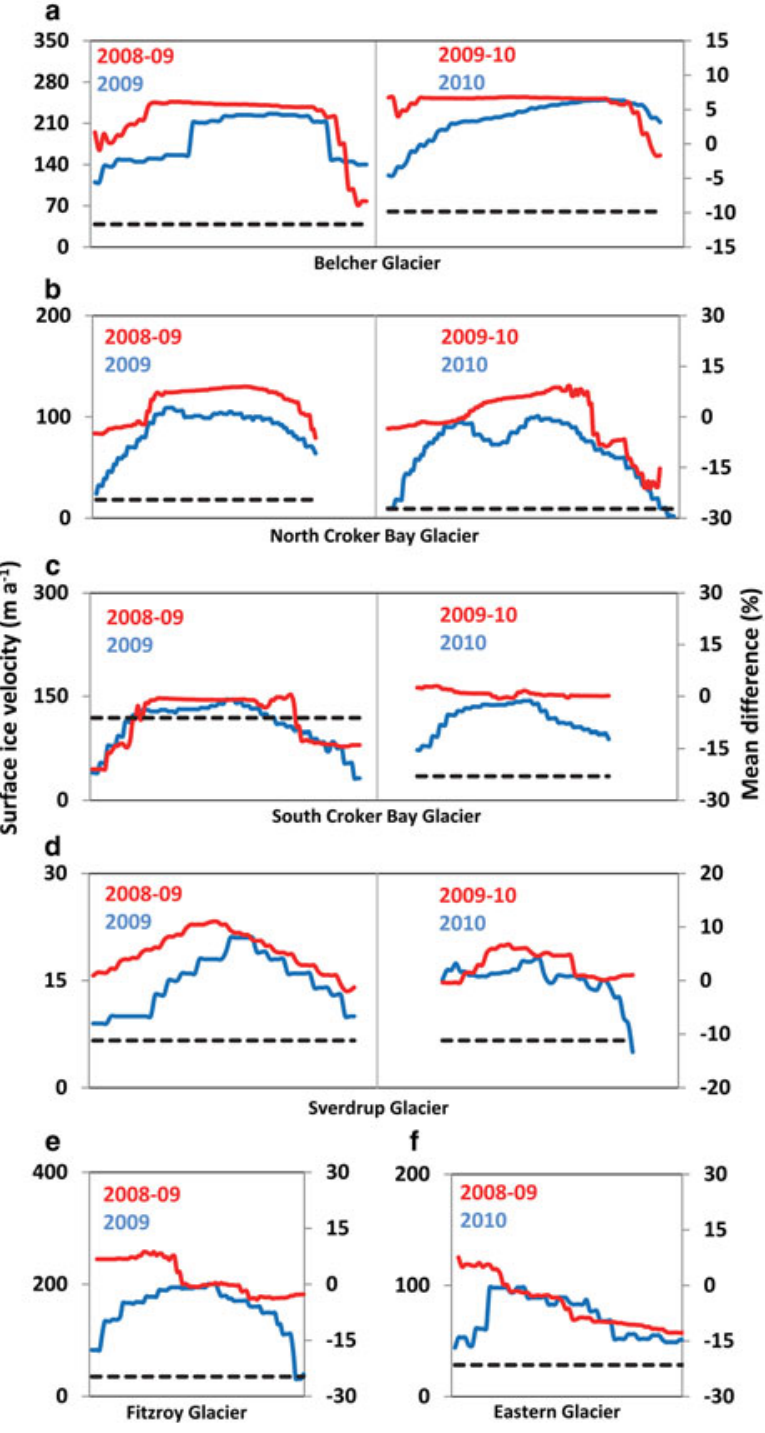

Fig. 2. Comparison of near terminus velocities at flux gates (see Fig. 1 for location) derived from feature tracking (red line) and speckle tracking (blue line) for: (a) Belcher Glacier, (b) North Croker Bay Glacier, (c) South Croker Bay Glacier, (d) Sverdrup Glacier, (e) Fitzroy Glacier, (f) Eastern Glacier. Dashed lines indicate mean percent difference between feature tracking and speckle tracking velocities across each terminus flux gate.

Belcher Glacier was $\sim 0.2$ m over a 15-20-day period in the early summer, after which the glacier undergoes negative vertical motion (deflates $0.2-0.3 \mathrm{~m}$ ) over the remainder of the summer (Danielson and Sharp, 2013; Fig. 4). As such, any vertical motion would have a negligible impact on the horizontal velocities derived over the annual timescale of the Landsat measurements, or the winter period of the Radarsat-2 measurements, and would not cause significant discrepancies between velocities derived from the two methods.

\subsubsection{Variability in annual motion 1999-2010}

Surface velocity fields of eight major outlet glaciers were derived by feature tracking applied to Landsat-7 ETM+ image pairs acquired annually between 1999 and 2010 (Fig. 3). Belcher Glacier (Fig. 3a) and Fitzroy Glacier (Fig. 3c) have similar velocity characteristics, with velocities beginning to increase $5-7 \mathrm{~km}$ from their fronts and reaching the maximum values of $260-300 \mathrm{~m} \mathrm{a}^{-1}$ at their termini. Neither glacier displayed any velocity variability in excess of the error margins for feature tracking during the period 1999-2010. The maximum velocities $\left(\sim 150 \mathrm{~m} \mathrm{a}^{-1}\right)$ of Southeast-1 and Southeast-2 glaciers occurred in the upper regions of the main trunks of both glaciers, 25-45 km from their shared terminus, in 1999/2000. Velocities in these regions began to decrease after this time, reaching $60-100 \mathrm{~m} \mathrm{a}^{-1}$ by $2000 / 01$. Velocities in the shared terminus region of the two glaciers were close to zero over the 19992010 period (Figs 3e, g).

Longitudinal velocity profiles of North Croker Bay Glacier (Fig. 3i) varied considerably. The lowest velocities in the lower $15 \mathrm{~km}$ of the glacier $\left(50-100 \mathrm{~m} \mathrm{a}^{-1}\right.$ ) were measured in 2002/03, but velocities here increased abruptly to 100 $140 \mathrm{~m} \mathrm{a}^{-1}$ in 2003/04 and reached maximum values of $150-200 \mathrm{~m} \mathrm{a}^{-1}$ in 2005/06. They then decreased in each subsequent year to $2009 / 10$. The greatest velocity variation occurred in the lower $5 \mathrm{~km}$ of the glacier, where velocities increased from $\sim 50 \mathrm{~m} \mathrm{a}^{-1}$ in $2001 / 02$ to $180-200 \mathrm{~m} \mathrm{a}^{-1}$ by $2005 / 06$ (Fig. 3i). The nearby South Croker Bay Glacier displayed much less interannual variability (Fig. 3k), with peak velocities along the lowermost $20 \mathrm{~km}$ section of the glacier ranging between 120 and $180 \mathrm{~m} \mathrm{a}^{-1}$ in nearly all years from 1999 to 2010. Anomalously high velocities of $\sim 240 \mathrm{~m} \mathrm{a}^{-1}$ occurred in the lowermost terminus region in 2005/06. However, the temporal pattern of velocity fluctuations over the observation period was broadly similar between the two glaciers, with lower velocities in 2001/02 and 2002/03, maximum velocities in 2005/06 and deceleration of the glacier in later years of observation.

\subsubsection{Variability in winter motion 2009-15}

Speckle tracking of RADARSAT-2 imagery generated surface velocity fields for nearly all the major outlet glaciers of Devon Ice Cap for the winters of 2009-15 (Fig. 3). From 2009 to 2014 the speckle tracking-derived velocity structure of Belcher Glacier (Fig. 3a) was similar to the pattern derived from the feature tracking results, with velocities increasing in the lower $10 \mathrm{~km}$ of the glacier and reaching the maximum values of $250-300 \mathrm{~m} \mathrm{a}^{-1}$ in the lowermost terminus region. The interannual velocity variability in this period was generally within error margins, but motion in winter 2015 was distinctly faster than observed in all other years by either speckle tracking or feature tracking, particularly in the lowermost $3 \mathrm{~km}$ of the glacier.

The speckle tracking velocity structure of Fitzroy Glacier (Fig. 3b) is also very similar to that described from the feature tracking results. The 2015 velocities are significantly lower than those determined for all other years, especially in the section of the glacier located between 2 and $5 \mathrm{~km}$ from the calving front (Fig. 3f). The magnitude of this slowdown is greater than the $10-20 \%$ variability associated with seasonality, and builds on a multi-year slowdown over the speckle tracking measurement period. Speckle tracking derived velocity fields of Southeast-1 (Fig. 3g) and Southeast-2 glaciers (Fig. 3f) reveal continued deceleration of the upper sections of both glaciers (25-45 km from the terminus). However, velocities have increased to $>100 \mathrm{~m} \mathrm{a}^{-1}$ in the lowermost $2-5 \mathrm{~km}$ of both glaciers (roughly doubling between 2009 and 2015, and significantly higher than the values determined for that region between 1999 and 2010). 
a

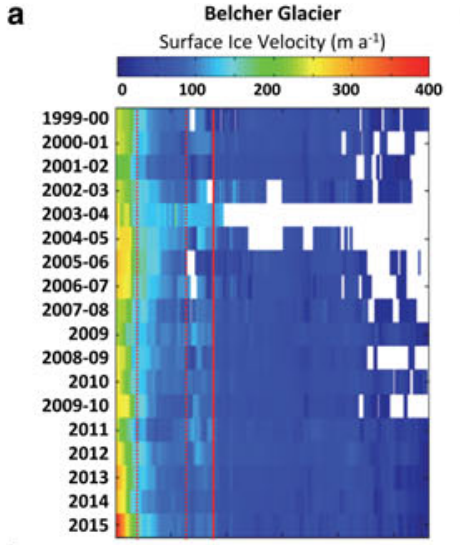

b

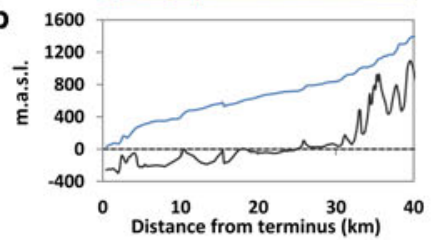

g

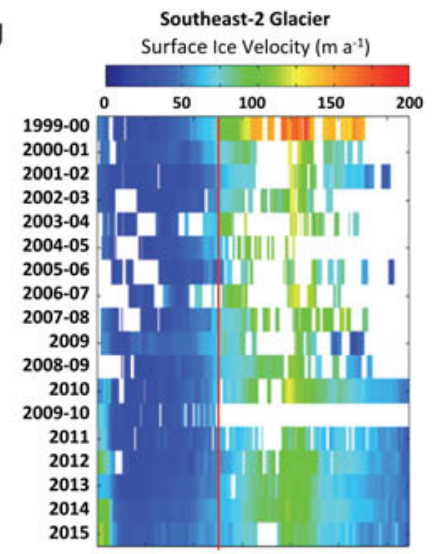

h

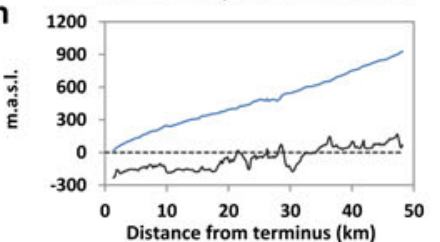

m

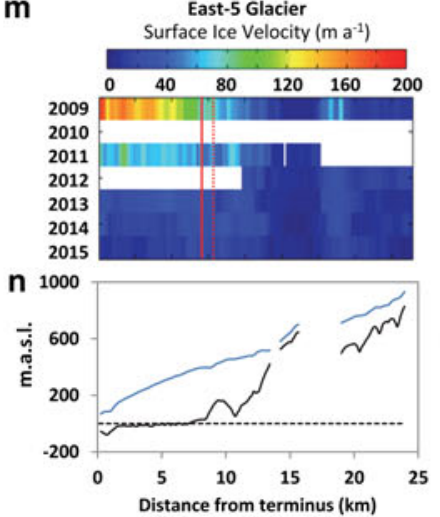

C

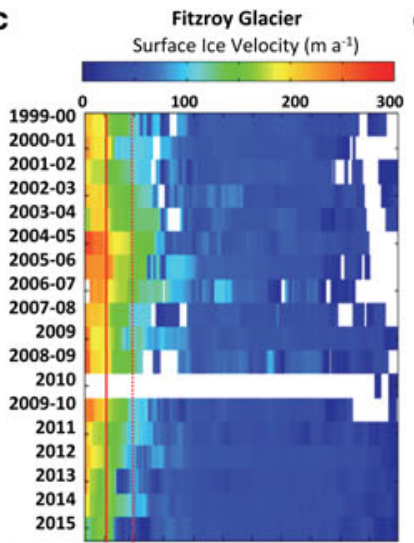

d 800

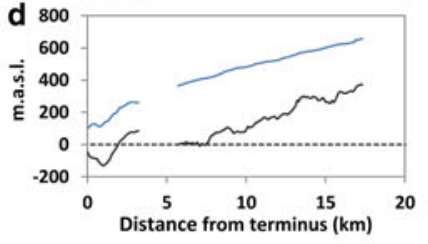

i

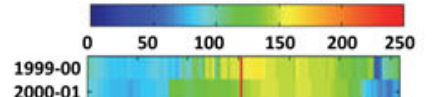

2000-01.

2001-02

2002-03

2003-04

2004-05.

2005-06

\begin{tabular}{|r|r|}
$2006-07$ \\
$2007-08$
\end{tabular}

2009.

$2008-09$
2010
$2009-10$

2009-10

2011

2012

2014

j 1200

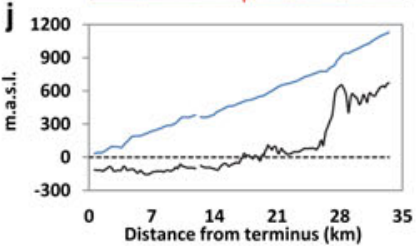

o

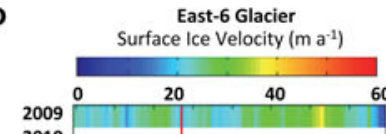

2009

2010
2011
2012
2013

2014
2015

p 500

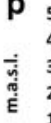

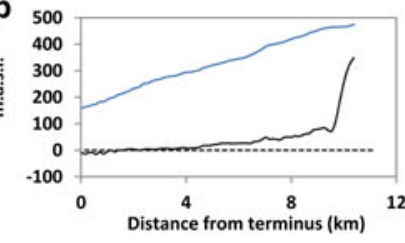

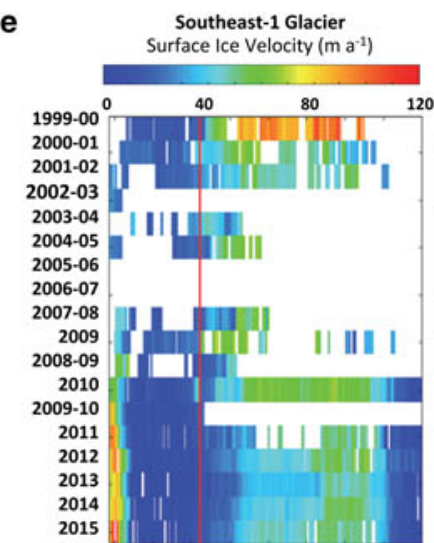

$f_{1200}$
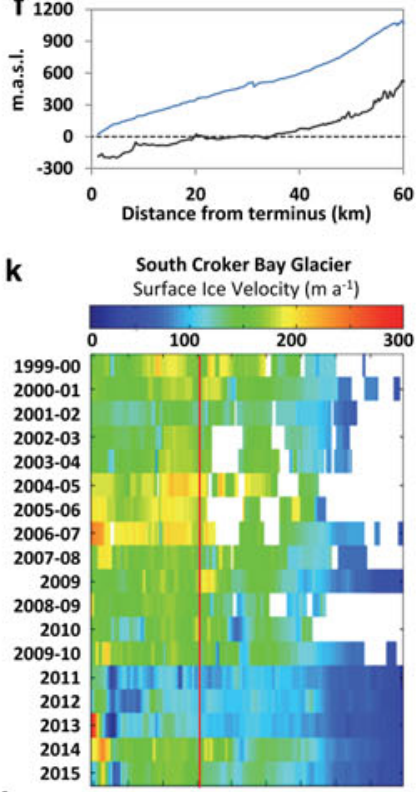

I 1200

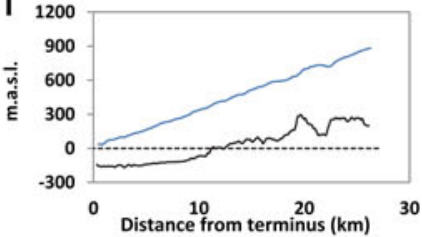

9
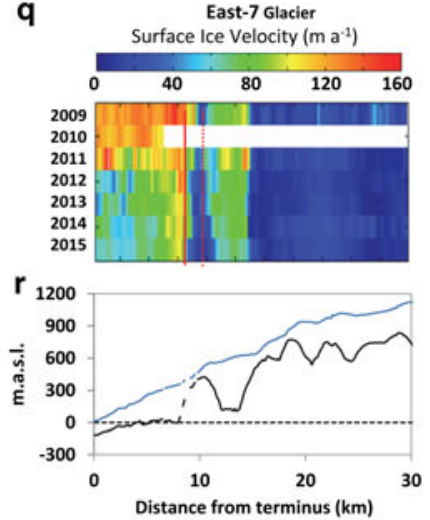

- Bed elevation _.......- Sea level _ Surface elevation

Fig. 3. Extracted velocities derived from feature tracking (1999-2010) and speckle tracking (2009-15) along the centerlines of Belcher (BL-BL' on Fig. 1), Fitzroy (FZ-FZ' on Fig. 1), Southeast-1 (SE1-SE1' on Fig. 1) Southeast-2 (SE2-SE2' on Fig. 1), North Croker Bay (NCB-NCB' on Fig. 1) and South Croker Bay (SCB-SCB') glaciers, respectively' (a, c, e, g, l, k); Extracted velocities derived from speckle tracking (2009-15) along the centerlines of East-5 (E5-E5' on Fig. 1), East-6 (E6-E6' on Fig. 1) and East-7 (E7-E7') glaciers, respectively: (m, o, q); (b, d, f, h, j, l, n, p, r) Bed and surface elevation profiles. Solid red lines denote the location where the glacier bed descends below sea level, red dashed lines indicate basal topographic features (sills, bedrock bumps) that influence ice motion for glaciers described in text. 
Speckle tracking velocities reveal that North Croker Bay Glacier decelerated (by 50-70 $\mathrm{m} \mathrm{a}^{-1}$ ) between 2010 and 2011, with low values persisting along its entire length from 2011 to 2015 (Fig. 3i), similar to the situation during the period of slow flow from 2001 to 2004. South Croker Bay Glacier's velocity field (Fig. 3k) was generally similar to that determined by feature tracking, with the notable exception of winters 2011-13, when velocities along the section $1-15 \mathrm{~km}$ from the terminus were $50 \%$ lower than in all other years.

East-5 Glacier (Fig. 3m) had surface velocities of 100-175 $\mathrm{m} \mathrm{a}^{-1}$ in its lowermost $10 \mathrm{~km}$ in 2009 . These decreased to $\sim 50 \mathrm{~m} \mathrm{a}^{-1}$ in winter 2011 and approached zero from 2013 to 2015. East-6 Glacier (Fig. 3o) typically had low velocities (10-35 $\mathrm{m} \mathrm{a}^{-1}$ ) throughout its lower section. This glacier slowed by $\sim 20 \mathrm{~m} \mathrm{a}^{-1}$ between 2010 and 2011, and velocities in 2015 were the lowest in the entire observation period. Finally, velocities of East-7 Glacier (Fig. 3q) peaked in winter 2009 over the entire lower $15 \mathrm{~km}$ of the glacier and thereafter decreased significantly (beyond error limits) in each subsequent year until winter 2015, when the lowest recorded velocities were observed along the entire length of the glacier.

\subsection{Bed morphology and areas of dynamic variability}

It is notable that the areas of greatest velocity variability typically occur in locations where the bed descends below sea level (Fig. 3). This relationship is clearest for Belcher Glacier (Fig. 3b), North Croker Bay Glacier (Fig. 3j), East-5 Glacier (Fig. 3n) and East-7 Glacier (Fig. 3r). Up-glacier of the locations where the bed descends below sea level, ice velocities typically display much less variability between years. These findings suggest that the bed morphology, and possibly a transition from bedrock to marine sediments at the glacier bed where it is below sea level (Dowdeswell and others, 2004), play significant roles in regulating on the flow of Devon Ice Cap. On Belcher Glacier, for example, the region where velocity increased from 2009 to 2015 was grounded below sea level, while the region of velocity decrease was located where the bed rises above sea level. The point at which the bed descends below sea level thus appears to divide the glacier into regions with different dynamic behaviors.

Bed elevation profiles also suggest that bedrock bumps located up-glacier of the point where the bed descends below sea level may influence the surface motion of some outlet glaciers. Such bedrock bumps are apparent in the bed profiles of both Fitzroy (Fig. 3d) and East-7 (Fig. 3r) Glaciers in locations where they slowed down most dramatically between 2009 and 2015 (Figs 3c q). The flow of East-7 Glacier over the bedrock bump is consistently slower than in regions located both up-glacier and down-glacier from it.

\subsection{Flow regime mapping}

Our flow regime mapping (Fig. 4) indicates that FR1 is the most extensive $(84.45 \%$ of the ice-cap area) flow region on Devon Ice Cap, and that it covers most of the ice cap's upper interior plateau regions. FR2 $(14.27 \%$ of the ice-cap area) is found primarily along the upper portions of the main trunks of outlet glaciers, while FR3 $(1.00 \%$ of the icecap area) occurs in the lower sections of some, but not all, major outlet glaciers (Belcher, Fitzroy, South Croker Bay, East-7) and in a small area located $30 \mathrm{~km}$ from the terminus of Southeast-2 Glacier. FR4 $(0.28 \%$ of the ice-cap area) is

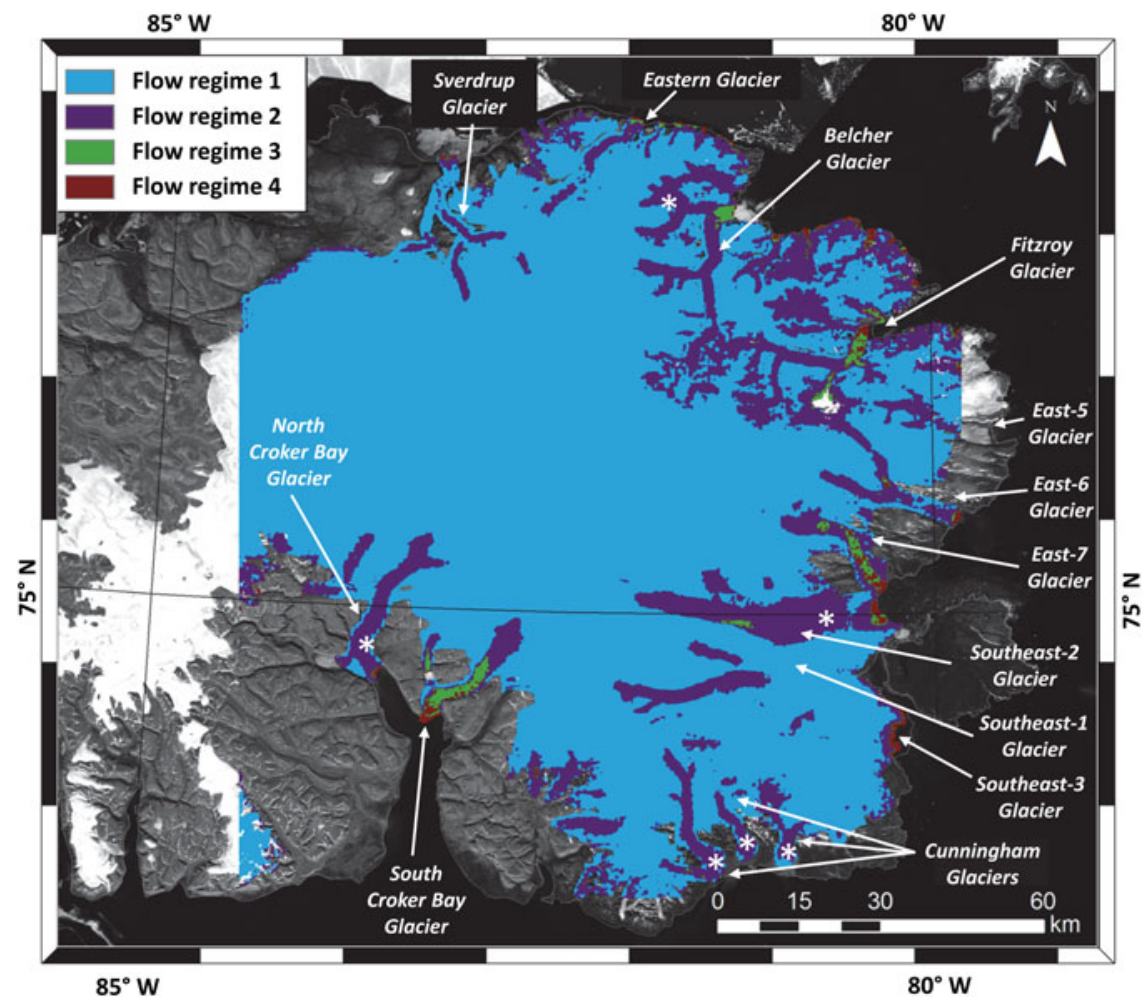

Fig. 4. Flow regime map of Devon Ice Cap overlain on a Landsat-7 image mosaic acquired 29 July and 2 August 2000 . $^{\text {*’ }}$ indicates areas classified as flow regimes different from those derived by Burgess and others (2005) (FR1, indicates ice frozen to its bed, motion by internal deformation only; FR2, indicates basal ice approaching pressure-melting point, enhanced motion; FR3, indicates reduction in ice viscosity, greater basal contribution to ice motion; FR4, high basal motion, deformation of basal sediments). 
found in the lowermost terminus regions of Belcher, South Croker, Fitzroy, East-7 and Southeast-2 Glaciers.

There are some differences between the flow regime map produced in this study and the previous map of Burgess and others (2005). Areas of difference include the two major tributary arms of Belcher Glacier (which change from FR3 to FR2), the Cunningham Glaciers (which change from FR3/4 to FR2), the main trunk of the North Croker Bay Glacier (which changed from FR3/4 to FR2) and the shared terminus region of the Southeast- 1 and Southeast-2 Glaciers (which changed from FR1 to FR2).

\subsection{Dynamic discharge}

Dynamic discharge estimates derived for individual glaciers of Devon Ice Cap from Landsat-7 ETM+ and RADARSAT-2 datasets are presented in Tables 3 and Table 4, respectively. For Devon Ice Cap as a whole, the average dynamic discharge over the period for which speckle tracking data are available (2009, 2011-15) was $0.41 \pm 0.11 \mathrm{Gt} \mathrm{a}^{-1}$ (Table 4) which is within the error margins of previous estimates of dynamic discharge from the ice cap (e.g. $0.39 \pm 0.08 \mathrm{Gt}$ $\mathrm{a}^{-1}$ (Burgess and others, 2005); $0.40 \pm 0.09 \mathrm{Gt} \mathrm{a}^{-1}$ (Van Wychen and others, 2012); $0.35 \pm 0.14 \mathrm{Gt} \mathrm{a}^{-1} \quad$ (Van Wychen and others, 2014)). For comparison, the dynamic discharge reported here indicates that Devon Ice Cap is the second largest source of dynamic discharge for the QEI, behind the Prince of Wales Icefield $\left(1.80 \pm 0.44 \mathrm{Gt} \mathrm{a}^{-1}\right.$ in 2014) but ahead of the Northern Ellesmere Ice Cap (0.23 \pm $0.12 \mathrm{Gt} \mathrm{a}^{-1}$ in 2015), Agassiz Ice Cap $\left(0.15 \pm 0.11 \mathrm{Gt} \mathrm{a}^{-1}\right.$ in 2015), Steacie and Müller Ice Caps $\left(0.05 \mathrm{Gt} \mathrm{a}^{-1}\right.$ in 2015), Sydkap Ice Cap $\left(0.04 \pm 0.01 \mathrm{Gta}^{-1}\right.$ in 2015) and Manson Ice Cap (0.02 $\pm 0.01 \mathrm{Gt} \mathrm{a}^{-1}$ in 2015) (Van Wychen and others, 2016).

It is notable that the total dynamic discharge from the Devon Ice Cap was relatively constant between years, despite the large variability in the motion of individual glaciers. This suggests that as the contributions of some glaciers to total discharge diminish, those of others increase to offset the decreases. This seems to be a common characteristic of ice caps in the Canadian High Arctic (Van Wychen and others, 2014, 2016).

\section{DISCUSSION}

\subsection{Classification of glaciers: 'surging', 'pulsing' and 'consistent acceleration/deceleration'}

Van Wychen and others (2016) characterized the observed variability in the dynamics of the ice masses of Axel Heiberg and Ellesmere Islands as either 'surging', 'pulsing' or 'consistent acceleration' and we use that classification scheme to characterize the spatio-temporal evolution of the flow of Devon Ice Cap. In order for the variability to be attributed to 'surging', the glacier had to undergo multi-year periods of velocity variability, with evidence that fast flow initiated in upper regions and propagated down-glacier over time, and that velocity variability occurred over the entire length of the glacier (though not necessarily simultaneously). In addition, this velocity pattern needed to be combined with additional evidence of surging; such as geomorphic features that indicate non-steady flow (e.g. looped moraines, extensive fresh crevassing and digitate termini), or to have been identified as surge-type glaciers in

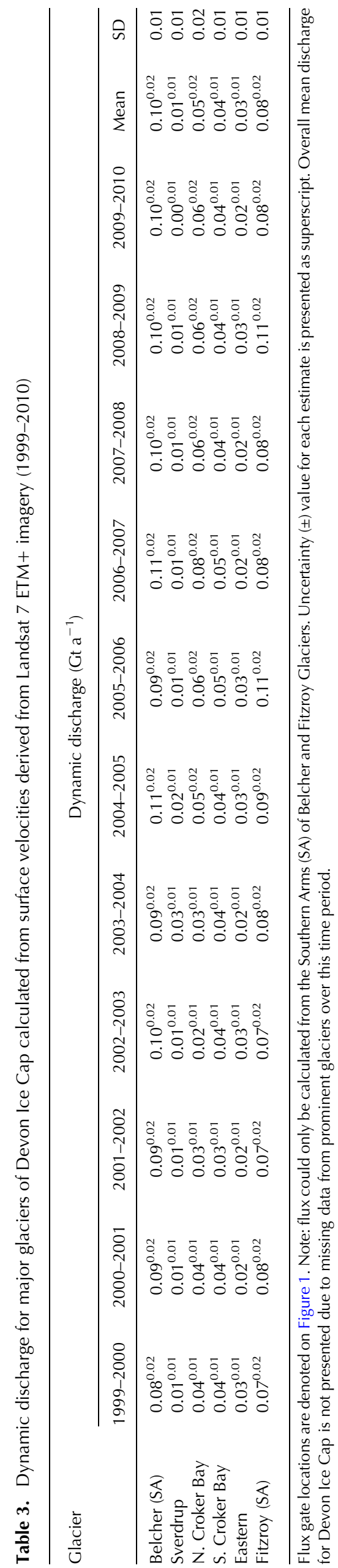


Table 4. Dynamic discharge for Devon Ice Cap calculated from Radarsat-2 derived surface ice velocities

\begin{tabular}{|c|c|c|c|c|c|c|c|c|c|}
\hline \multirow[t]{2}{*}{ Glacier } & \multicolumn{9}{|c|}{ Dynamic discharge $\left(\mathrm{Gt}^{-1}\right)$} \\
\hline & 2009 & 2010 & 2011 & 2012 & 2013 & 2014 & 2015 & Mean & SD \\
\hline Belcher (SA) & $0.11^{0.01}$ & $0.12^{0.01}$ & $0.11^{0.02}$ & $0.13^{0.01}$ & $0.14^{0.01}$ & $0.14^{0.01}$ & $0.17^{0.01}$ & $0.13^{0.01}$ & 0.02 \\
\hline Sverdrup & $0.01^{0.00}$ & $0.00^{0.00}$ & $0.01^{0.00}$ & $0.01^{0.01}$ & $0.01^{0.00}$ & $0.01^{0.00}$ & $0.01^{0.01}$ & $0.01^{0.00}$ & 0.00 \\
\hline N. Croker Bay & $0.06^{0.01}$ & $0.06^{0.01}$ & $0.02^{0.01}$ & $0.01^{0.01}$ & $0.01^{0.00}$ & $0.02^{0.00}$ & $0.01^{0.01}$ & $0.03^{0.01}$ & 0.02 \\
\hline Eastern & $0.03^{0.00}$ & & $0.03^{0.01}$ & $0.03^{0.01}$ & $0.01^{0.01}$ & $0.02^{0.01}$ & $0.01^{0.01}$ & $0.02^{0.01}$ & 0.01 \\
\hline Fitzroy (NA) & $0.00^{0.01}$ & & $0.01^{0.01}$ & $0.00^{0.01}$ & $0.00^{0.01}$ & $0.00^{0.01}$ & $0.00^{0.01}$ & $0.00^{0.01}$ & 0.00 \\
\hline Fitzroy (SA) & $0.08^{0.01}$ & & $0.09^{0.01}$ & $0.09^{0.01}$ & $0.08^{0.01}$ & $0.09^{0.01}$ & $0.08^{0.01}$ & $0.09^{0.01}$ & 0.01 \\
\hline East 5 & $0.05^{0.01}$ & & $0.03^{0.01}$ & & $0.01^{0.00}$ & $0.01^{0.01}$ & $0.00^{0.00}$ & $0.02^{0.01}$ & 0.02 \\
\hline East 6 & $0.00^{0.00}$ & & $0.01^{0.00}$ & $0.00^{0.01}$ & $0.01^{0.00}$ & $0.00^{0.00}$ & $0.00^{0.00}$ & $0.00^{0.00}$ & 0.00 \\
\hline East 7 & $0.04^{0.00}$ & $0.04^{0.01}$ & $0.03^{0.01}$ & $0.02^{0.01}$ & $0.02^{0.00}$ & $0.02^{0.01}$ & $0.02^{0.01}$ & $0.05^{0.02}$ & 0.01 \\
\hline Southeast $1 / 2$ & $0.04^{0.02}$ & $0.03^{0.02}$ & $0.05^{0.02}$ & $0.05^{0.02}$ & $0.04^{0.01}$ & $0.05^{0.02}$ & $0.06^{0.02}$ & $0.05^{0.07}$ & 0.01 \\
\hline Southeast 3 & $0.02^{0.01}$ & & $0.02^{0.01}$ & $0.02^{0.01}$ & $0.01^{0.01}$ & $0.01^{0.01}$ & $0.01^{0.01}$ & $0.02^{0.01}$ & 0.01 \\
\hline
\end{tabular}

Location of flux gates are denoted on Figure 1. Flux from Belcher and Fitzroy glaciers are calculated separately for the Northern Arm (NA) and Southern Arm (SA) of each glacier. Uncertainty $( \pm)$ value for each estimate is presented as superscript.

previous studies (e.g. Copland and others, 2003; Burgess and Sharp, 2008). For multi-year periods of velocity variability to be characterized as 'pulsing', there had to be evidence that the variability in ice motion was initiated at, or near, the calving front, that it was restricted largely to areas of the glacier that are grounded below sea level, and that it did not propagate up-glacier beyond the point where the bed rises above sea level. Several 'pulse-type' glaciers also had prominent bedrock bumps or sills located near their termini, and the greatest variability in ice motion occurred down-glacier of these points (Van Wychen and others, 2016). For a glacier to be identified as undergoing 'consistent acceleration' there had to be evidence of a nearly continuous increase in glacier velocities over the observation period but no evidence of previous surge activity or sills that would induce pulsing (Van Wychen and others, 2016).

\subsubsection{Velocity variability attributed to surging}

We attribute the velocity variability of the Southeast- 1 and Southeast-2 Glaciers to surging. The velocity variability of these glaciers has previously been attributed to surging (Burgess and Sharp, 2008; Van Wychen and others, 2012) and the results presented here support this interpretation. Faster ice motion began in the upper regions of both glaciers and spread down-glacier over the observation period, which is consistent with classic surge theory (Sharp, 1988) and the classification scheme of Van Wychen and others (2016). Thickening of the shared terminus region of the Southeast-1 and Southeast-2 Glaciers has been reported in previous studies (Burgess and Sharp, 2008; Gardner and others, 2011) and has been attributed to faster moving ice from the upper regions of the Southeast basin running into slower moving ice located in the lower sections of the glaciers. The longer-term velocity record presented here (Figs 3e, g) provides further support for this interpretation. The downglacier propagation of a surge front also explains why the flow regime in the shared terminus section of the southeast basin has changed from FR1 to FR2 (Fig. 4). As the surge traveled through the glacier as a kinematic wave, it initiated faster flow, probably by basal motion, in the lowermost terminus region. Unlike traditional surging, however, where the terminus is expected to advance as the surge front propagates down-glacier, the termini of Southeast- 1 and Southeast2 Glaciers retreated by $\sim 1800 \mathrm{~m}$ between 2000 and 2016. It is possible that this is the result of increased iceberg calving driven by elevated velocities as they reached the lowermost parts of these glaciers. Additionally, the fact that the bed of Southeast-1 and Southeast-2 Glaciers is grounded below sea level (Dowdeswell and others, 2004) may also be controlling the terminus response. Further work is required to more fully understand the mechanisms of the surge of Southeast- 1 and Southeast-2 Glaciers.

\subsubsection{Velocity variability attributed to pulsing}

We attribute the velocity variability of the Fitzroy (which had not been identified as a region of dynamic change by previous studies), East-5 and East-7 Glaciers to 'pulsing'. For Fitzroy Glacier, repeated velocity mapping indicates that the largest variation (deceleration) in ice motion occurred down-glacier of a prominent sill in the bed profile (located $1.5 \mathrm{~km}$ from the 2014 calving front; Figs 3c, d), where the glacier is grounded below sea level. In 2015, the greatest slowdown (compared with all other years of observation) occurred at the sill location.

Van Wychen and others (2012) reported that the surface velocities of East-5 Glacier were significantly higher in 2009 than in the mid-1990s, indicating that the glacier had accelerated over the intervening period. The velocity record presented here (Figs $3 \mathrm{~m}, \mathrm{n}$ ) indicates that the glacier has undergone a multi-annual slowdown since 2009 and that, by 2015, it had become nearly stagnant along most of its lowermost $10 \mathrm{~km}$ (returning to velocities similar to those of the mid-1990s). This region of slowdown is coincident with the locations of a prominent bedrock bump in the basal geometry (Fig. 3n), and the point where the elevation of the glacier bed first dips below sea level. This suggests that the bed morphology influences the dynamics of this glacier. Similarly, the region down-glacier of a prominent sill beneath East-7 Glacier slowed down significantly between 2009 and 2015 (Figs 3q, r).

These findings indicate that sills and bedrock bumps play an important role in regulating the flow of these glaciers. This 
is a characteristic shared with other glaciers on Axel Heiberg and Ellesmere Islands that were identified as pulse-type (Van Wychen and others, 2016). This suggests that basal motion is influenced by temporal variations in basal shear stress in regions grounded below sea level, possibly due to the influence of marine waters. However, further research is required to understand the driving mechanisms behind this process. These results also indicate that bedrock bumps can limit the spatial extent of the area of a glacier affected by velocity variability.

\subsubsection{Consistent acceleration}

After a period of limited velocity variability from 1999 to 2009, Belcher Glacier has undergone a multi-annual acceleration over its lower $15 \mathrm{~km}$, reaching its highest observed velocities in 2015, and a multi-annual deceleration in the region $20-40 \mathrm{~km}$ up-glacier from the terminus. These variations suggest that the glacier is currently undergoing a change in its dynamics. The highest level of velocity variability on Belcher Glacier occurs down-glacier of a sill located below sea level $2-3 \mathrm{~km}$ from the calving front, which is a common characteristic of 'pulse-type' glaciers (Van Wychen and others, 2016). However, it is also evident that velocities at this sill location never approached stagnation during the 15-year observation period (as has been observed on other glaciers that have been identified as 'pulse-type' on Devon Ice Cap (e.g. Fitzroy; East-5, East-7 Glaciers; Section 5.1.2) or elsewhere in the Canadian Arctic (e.g. Parrish and Dobbin Glaciers (Van Wychen and others, 2016)). The progressive speedup of Belcher Glacier between 2009 and 2015 (Fig. 3e) is similar to the 'consistent acceleration' observed on the Trinity and Wykeham Glaciers of Prince of Wales Icefield, which was likely driven by terminus thinning that facilitated faster ice flow (Van Wychen and others, 2016).

This study classified the northern arm of the Belcher Glacier as FR2, while Burgess and others (2005) classified it as FR3, which might suggest a change in dynamics in this area. However, this study does classify some portions of the northern arm of Belcher Glacier as FR3 in some years. The discrepancy in derived flow regimes between the results presented here and Burgess and others (2005) likely does not represent a real change in dynamics, but rather that the flow regime at this location is sensitive to small changes in data inputs (e.g. due to uncertainty in input data) as it lies at the threshold between FR2 and FR3 flow regimes.

\subsubsection{Other forms of velocity variability}

The velocity variability observed on the North and South Croker Bay Glaciers appears to differ from that associated with 'surging', 'pulsing' and 'consistent acceleration' behaviors. Other mechanisms are therefore needed to explain their dynamics. Both glaciers have undergone multi-year periods of slowdown and speedup associated with 'pulse' and 'surge' mechanisms, but the 15-year velocity record presented here indicates that at no time did either of these glaciers slow to complete stagnation (which would indicate a surge-type glacier in its quiescent phase). The surface velocities of both glaciers oscillated between periods of faster and slower flow over unequal time intervals (e.g. 3 years of relatively slow flow, followed by 9 years of faster flow, followed by 5 years of slow flow for North Croker Bay Glacier
(Fig. 4k)). These patterns of velocity variation are inconsistent with the pattern observed on surge-type glaciers within the Canadian Arctic Archipelago, which typically undergo relatively long periods of slow (quiescent) flow (e.g. 30-40 years) and shorter periods of faster (surge) flow (e.g. 5-7 years) (Copland and others, 2003; Van Wychen and others, 2016). For these reasons, the North Croker Bay and South Croker Bay Glaciers do not fit the classification of a 'surgetype' glacier. However, we are also unable to classify these glaciers as 'pulse-type' as: (i) velocity variability appears to occur simultaneously over the entire main trunk of both glaciers; (ii) it does not appear to originate at or near the calving front; and (iii) the velocity slowdown occurs up-glacier of the point where the bed rises above sea level. Thus, some other mechanism appears to be causing the variability in motion of the Croker Bay Glaciers; however, more in situ data (e.g. ocean and air temperatures) are required to determine whether or not a regional environmental control is regulating their flow. Whatever mechanism is driving their velocity variability, it has been enough to cause the main trunk of the North Croker Bay Glacier to transition from FR3/4 to FR2 in recent years, a change which suggests that the main trunk of the glacier has become more viscous over that time period and that the variability in dynamics of these two glaciers are distinct from all other glaciers in the Queen Elizabeth Islands.

\subsection{Dynamic discharge}

Given the large degree of variability in ice motion discussed above, it is of value to determine how dynamic discharge has changed over time. Table 3 presents the dynamic discharge calculated for 1999-2010 using feature tracking of Landsat7 ETM+ imagery, while Table 4 presents the dynamic discharge for 2009-15 derived from speckle tracking of RADARSAT-2 data. The dynamic discharge of Devon Ice Cap is dominated by the fluxes from a few key glaciers, with Belcher, Fitzroy, Southeast- 1 and Southeast-2 Glaciers accounting for $66 \%$ of the total dynamic discharge over the observation period. Belcher Glacier is the single largest contributor, accounting for between $23 \%$ of the total dynamic discharge in winter 2009 and $42 \%$ in winter 2015, or an average of $32 \%$ over the study period. Conversely, multiyear slow-downs of Eastern, North Croker Bay, East-5 and East-7 Glaciers have resulted in decreased dynamic discharge (beyond error margins) from these glaciers in recent years. The decrease in dynamic discharge from East-5 and North Croker Bay Glaciers has been the most significant, with each glacier accounting for $12 \%$ of total dynamic discharge in winter 2009, but only 2\% in winter 2015.

\section{CONCLUSIONS}

Feature tracking using Landsat-7 ETM+ imagery and speckle tracking using RADARSAT-2 imagery have generated the longest record of velocity variations on Devon Ice Cap to date. The results provide insight into the timescales of variability in glacier dynamics in the Canadian Arctic. The dynamics of Devon Ice Cap are more variable than previously recognized, with significant variations in the motion of the North Croker Bay, South Croker Bay, East-6 and East-7 Glaciers that were not revealed by earlier studies (e.g. Van Wychen and others, 2012). Velocity mapping indicates that significant dynamic changes can occur on both relatively short (e.g. 1-3 years: 
North Croker Bay Glacier) and longer (e.g. 10-15 years: Southeast-1, Southeast-2 Glaciers) timescales. These timescales are likely associated with changes driven by different dynamic processes. We have updated and expanded the mapping of ice-cap flow regimes originally undertaken by Burgess and others (2005), and find that basal sliding has become a component of the motion of the shared terminus region of the Southeast- 1 and Southeast-2 Glaciers, while the trunk of the North Croker Bay Glacier appears to have become more resistant to flow over time.

Using the 'surge', 'pulse' and 'consistent acceleration' classification scheme proposed by Van Wychen and others (2016), 'surging' is able to describe the velocity variability of the Southeast-1, Southeast-2 Glaciers, while 'pulsing' behavior describes the velocity variability of Fitzroy, East-5, East-7 Glaciers. The recent speedup of Belcher Glacier is classified as 'consistent acceleration' and is reminiscent of the recent speedup reported for Trinity and Wykeham Glaciers on Ellesmere Island (Van Wychen and others, 2016). However, more study is required to determine whether this recent speedup will be a prolonged event. The dynamics of North Croker Bay and South Croker Bay glaciers do not fit well within this classification scheme, suggesting that behaviors different from those associated with 'surging', 'pulsing' and 'consistent acceleration' may describe the dynamics of these two glaciers. The synchronous velocity responses of the North Croker Bay and South Croker Bay Glaciers suggest that a common external forcing mechanism (e.g. oceanic or atmospheric) may be influencing their flow, but more in situ data are needed to identify what this forcing may be.

The average annual dynamic discharge from Devon Ice Cap over the periods 2009 and 2011-15 was $0.41 \pm$ $0.11 \mathrm{Gt} \mathrm{a}^{-1}$, with approximately two-thirds of all discharge coming from four glaciers (Belcher, Fitzroy, Southeast-1 and Southeast-2). This consistent ice-cap wide discharge occurs despite the slowdown of six of the tidewater terminating glaciers during the study period, because their decreasing discharge was compensated for by increased discharge from the Belcher, Fitzroy, Southeast-1 and Southeast-2 Glaciers. These findings are consistent with those of previous studies (e.g. Burgess and others, 2005; Van Wychen and others, 2012, 2016), and do not suggest any long-term change in mean discharge from the ice cap since the mid-1990s, despite regional variability in glacier dynamics.

\section{ACKNOWLEDGEMETS}

We acknowledge NSERC (Discovery Grants and Northern Research Supplements to LC and MS), the Canada Foundation for Innovation, Ontario Research Fund, Alberta Innovates Technology Futures, ArcticNet, Transport Canada, Ontario Graduate Scholarship, and the Polar Continental Shelf Project (Natural Resources Canada) for support of this work. DB is supported by the Climate Change Geoscience Program, Earth Sciences Sector, Natural Resources Canada (Contribution \#20150442). RADARSAT-2 data were provided through MacDonald, Dettwiler and Associates under the RADARSAT-2 Government Data Allocation administered by the Canadian Space Agency and acquired via Natural Resources Canada. All Operation IceBridge data were downloaded from the National Snow and Ice Data Center (https:// nsidc.org/data/icebridge/) and we thank NASA's Operation IceBridge (especially John Sonntag) for supporting the collection of ice thickness datasets for Devon Ice Cap. Data acquisition during UK airborne radar surveys was funded through UK Natural Environment Research Council (NERC) grants GR3/12469 and NE/K004999.

\section{REFERENCES}

Burgess DO and Sharp MJ (2004) Recent changes in areal extent of the Devon ice cap, Nunavut, Canada. Arct. Antarct. Alp. Res., 36(2), 261-271 (doi: 10.1657/1523-0430(2004)036 [0261:RCIAEO]2.0.CO;2)

Burgess DO and Sharp MJ (2008) Recent changes in thickness of the Devon Island ice cap, Canada. J. Geophys. Res., 113(B7), B07204 (doi: 10.1029/2007JB005238)

Burgess DO, Sharp MJ, Mair DWF, Dowdeswell JA and Benham TJ (2005) Flow dynamics and iceberg calving rates of Devon Ice Cap, Nunavut, Canada. J. Glaciol., 51(173), 219-230 (doi: 10.3189/172756505781829430)

Copland L, Sharp MJ and Dowdeswell J (2003) The distribution and flow characteristics of surge-type glaciers in the Canadian High Arctic. Ann. Glaciol., 36, 73-81 (doi: 10.3189/ $172756403781816301)$

Cress P and Wyness R (1961) The Devon Island expedition, observations of glacial movements. Arctic, 14(4), 257-259.

Danielson B and Sharp MJ (2013) Development and application of a time-lapse photograph analysis method to investigate the link between tidewater glacier flow variations and supraglacial drainage events. J. Glaciol., 59(214), 287-302 (doi: 10.3189/ 2013JoG12J108)

Dowdeswell JA, Benham TJ, Gorman MR, Burgess DO and Sharp MJ (2004) Form and flow of the Devon Island ice cap, Canadian Arctic. J. Geophys. Res., 109(F2), F02002 (doi: 10.1029/ 2003JF000095)

Gardner AS and Sharp MJ (2007) Influence of the Arctic circumpolar vortex on the mass balance of Canadian high Arctic Glaciers. J. Climate, 20, 4586-4598 (doi: 10.1175/JCLI4268.1)

Gardner AS and 8 others (2011) Sharply increased mass loss from glaciers and ice caps in the Canadian Arctic Archipelago. Nature, 473(7347), 357-360 (doi: 10.1038/nature10089)

Gardner A, Moholdt G, Arendt A and Wouters B (2012) Accelerated contributions of Canada's Baffin and Bylot Island glaciers to sea level rise over the past half century. Cryosphere, 6, 1103-1125 (doi: 10.5194/tc-6-1103-2012)

Gogineni P (2012) Radar depth sounder data products. Digital Media, Lawrence, Kansas, USA. http://data.cresis.ku.edu/

Haug T, Kääb A and Skvarca P (2010) Monitoring ice shelf velocities from repeat MODIS and Landsat data - a method study on the Larsen C ice shelf, Antarctic Peninsula, and 10 other ice shelves around Antarctica. Cryosphere, 4, 161-178 (doi: 10.5194/tc-4-161-2010)

Koerner RM (1979) Accumulation, ablation, and oxygen isotope variations on the Queen Elizabeth Islands ice caps, Canada. I. Glaciol., 22(86), 25-41

Koerner RM (2005) Mass balance of glaciers in the Queen Elizabeth Islands, Nunavut, Canada. Ann. Glaciol., 42, 417-423 (doi: 10.3189/172756405781813122)

Lenaerts JTM and 5 others (2013) Irreversible mass loss of Canadian Arctic Archipelago glaciers. Geophys. Res. Lett., 40(5), 870-874 (doi: 10.1002/grl.50214)

Mair DWF, Burgess DO and Sharp MJ (2005) Thirty-seven year mass balance of Devon Ice Cap, Nunavut, Canada, determined by shallow ice coring and melt modeling. J. Geophys. Res., 110 (F01011) (doi: 10.1029/2003JF000099)

Paterson WSB (1994) The physics of glaciers, 3rd edn. Elsevier Science Ltd

Pfeffer WT and 18 others and the Randolph Consortium (2014) The randolph glacier inventory: a globally complete inventory of glaciers. J. Glaciol., 60(221), 537-552 (doi: 10.3189/ 2014JoG13J176) 
Schellenberger T, Van Wychen W, Copland L, Kääb A and Gray L (2016) An inter-comparison of techniques for determining velocities of maritime Arctic glaciers, Svalbard, using Radarsat-2 Wide Fine mode data. Remote Sens., 8(9), 785 (doi: 10.3390/ rs8090785)

Sharp MJ (1988) Surging glaciers: behavior and mechanisms. Prog. Phys. Geogr., 12, 349-370 (doi: 10.1177/030913338801200302)

Sharp MJ and 5 others (2011) Extreme melt on Canada's Arctic ice caps in the 21st century. Geophys. Res. Lett., 38(L11501) (doi: 10.1029/ 2011GL047381)

Sharp MJ and 12 others (2014) Remote sensing of recent glacier changes in the Canadian Arctic. In Kargel JS, Leonard GJ, Bishop MP, Kääb A and Raup BH, eds. Global land ice measurements from space, Ch. 9. Praxis-Springer, Heidelberg, 205-228 (doi: 10.1007/978-3-540-79818-7_9)

Shepherd A, Du Z, Benham TJ, Dowdeswell JA and Morris EM (2007) Mass balance of Devon Ice Cap, Canadian Arctic. Ann. Glaciol., 46, 249-254 (doi: 10.3189/172756407782871279)

Short NH and Gray AL (2004) Potential for RADARSAT-2 interferometry: glacier monitoring using speckle tracking. Can. J. Remote Sens., 30(3), 504-509 (doi: 10.5589/m03-071)

Short NH and Gray AL (2005) Glacier dynamics in the Canadian High Arctic from RADARSAT-1 speckle tracking. Can. J. Remote Sens., 31(3), 225-239 (doi: 10.5589/m05-010)
Van Wychen W and 5 others (2012) Spatial and temporal variation of ice motion and ice flux from Devon Ice Cap, Nunavut, Canada. J. Glaciol., 58(210), 657-664 (doi: 10.3189/2012JoG11J164)

Van Wychen W and 6 others (2014) Glacier velocities and dynamic ice discharge from the Queen Elizabeth Islands, Nunavut, Canada. Geophys. Res. Lett., 41(2), 484-490 (doi: 10.1002/ 2013GL058558)

Van Wychen W, Copland L, Burgess D, Gray L and Schaffer N (2015) Glacier velocities and dynamic discharge from the ice masses of Baffin and Bylot Islands, Nunavut, Canada. Can. J. Earth Sci., 52(11), 980-989 (doi: 10.1139/cjes-2015-0087)

Van Wychen W and 6 others (2016) Characterizing interannual variability of glacier dynamics and dynamic discharge (1999-2015) for the ice masses of Ellesmere and Axel Heiberg Islands, Nunavut, Canada. J. Geophys. Res. Earth Surf., 121(1), 39-63 (doi: 10.1002/2015JF003708)

Waechter A, Copland L and Herdes E (2015) Modern glacier velocities across the Icefield Ranges, St. Elias Mountains, and variability at selected glaciers form 1959-2012. J. Glaciol., 61(228), 624634 (doi: 10.3189/2015JoG14J147)

Wyatt $F$ and Sharp M (2015) Linking surface hydrology to flow regimes and patterns of velocity variability of the Devon Ice Cap, Nunavut. J. Glaciol., 61(226), 387-399 (doi: 10.3189/ 2015JoG14J109)

MS received 18 July 2016 and accepted in revised form 6 January 2017; first published online 7 February 2017 